\title{
Response of Plant Fungal Diseases to Beef Cattle Grazing Intensity in Hulunber Grassland
}

\author{
Yawen Zhang, ${ }^{1}$ Zhibiao Nan, ${ }^{1, \dagger}$ and Xiaoping $\mathrm{Xin}^{2}$ \\ ${ }^{1}$ State Key Laboratory of Grassland Agro-ecosystems; Key Laboratory of Grassland Livestock Industry Innovation, Ministry of \\ Agriculture and Rural Affairs; College of Pastoral Agricultural Science and Technology, Lanzhou University, Lanzhou 730020, \\ P.R. China \\ ${ }^{2}$ National Hulunber Grassland Ecosystem Observation and Research Station, Institute of Agricultural Resources and Regional \\ Planning, Chinese Academy of Agricultural Science, Beijing 10081, P.R. China
}

\begin{abstract}
The effects of grazing by large herbivores on biodiversity and ecosystem functioning have been extensively studied, whereas how grazing influence plant diseases, especially in natural grasslands, remains poorly understood. Therefore, we undertook a field study regarding a grazing trial in a temperate meadow steppe grassland to investigate mechanisms underlying grazing-host-pathogen interactions. The effects of cattle grazing at different grazing intensities of $0,0.23,0.34,0.46,0.69$, and $0.92 \mathrm{AU} /$ ha (where $1 \mathrm{AU}=500 \mathrm{~kg}$ of adult cattle) on the microenvironment, vegetation characteristics, and occurrence of diseases were evaluated. At the population level, the effects of grazing on grassland vegetation characteristics and disease varied with grassland plant species. Compared with nongrazing, grazing directly decreased the average density, coverage, and disease incidence of palatable and edible forages by 51.4, 62.4 , and $82.4 \%$ in the $0.92 \mathrm{AU} / \mathrm{ha}$ treatment but increased the occurrence and prevalence of disease in remaining small herbs by $752.1 \%$.

At the community level, with the increase of grazing intensity, the pathogen load of the whole community in grassland was positively related to host coverage. In addition, there was a trend toward increased microtemperature and decreased microhumidity with increased grazing. Although occurrence of plant diseases in natural grasslands is influenced by a range of factors, comprehensive analysis highlighted the major role that cattle grazing intensity plays in the occurrence of plant diseases in natural grasslands. In addition to its direct effect, grazing also indirectly affects disease occurrence by shifting plant community structure and the microenvironment. However, direct effects of grazing intensity affected disease occurrence more than indirect effects.

Keywords: cattle grazing intensity, seasonal changes, grazing-host-pathogen interactions, biodiversity, vegetation characteristic, microenvironment, community pathogen load
\end{abstract}

Grasslands occupy approximately $40 \%$ of Earth's land surface (Asner et al. 2004), and 90\% is used for grazing. Grasslands cover $41 \%$ of the total land area in China, with an area of 390 million ha (Wang et al. 2013). The Hulunber grasslands is one of the largest areas of natural temperate subhumid meadow grasslands in the world, located in northeastern China, covering an area of about 10 million $\mathrm{km}^{2}$ (Yan et al. 2015). It is both an important ecological barrier and a feedbase for animal husbandry production base in north China (Yan et al. 2016; Xun et al. 2018). However, plant diseases are one of the key factors limiting grassland productivity and sustainable development (Liu et al. 2016). Diseases impede plant growth, leading to a shortened period of productivity, reduced yield, and changed species composition (Fisher et al. 2012). For natural grasslands, while taking into consideration the ecological and economic benefits, disease mitigation measures should be focused on scientifically based and applicable management measures. Grazing and utilization practices of natural and sown grasslands provide one of the major management options, playing an important role in maintaining both the health of grasslands and the stability of grassland ecological

${ }^{\dagger}$ Corresponding author: Z. B. Nan; zhibiao@1zu.edu.cn

Funding: This research was financially supported by the National Public Welfare Industry of Agricultural Science and Technology Special Projects (201303057).

*The $\boldsymbol{e}$-Xtra logo stands for "electronic extra" and indicates there are supplementary materials published online.

The author(s) declare no conflict of interest.

Accepted for publication 6 May 2020.

(C) 2020 The American Phytopathological Society systems (Hou and Yang 2006; Nan and Li 2003; Skipp and Lambert 1984; Ylänne et al. 2018). Grazing is important in determining the diversity in vegetation types (Altesor et al. 2005; Marty 2005; Yan et al. 2015), the plant community structure (Briske et al. 2003; Kraaij and Milton 2006; Yang et al. 2018; Zhong et al. 2014), the soil microbial populations (Northup et al. 2013; Xun et al. 2018; Zhou et al. 2010), and the C:N:P stoichiometry (Bai et al. 2012). However, less well understood is how grazing will influence plant diseases, especially in natural grasslands.

Grazing disturbs the interaction between hosts and pathogens and, as such, influences the occurrence of grassland diseases (Liu 2008). Large herbivores are key drivers of plant community dynamics (Bardgett and Wardle 2003), affecting species composition and vegetation features of grasslands. The effects of grazing on species diversity depend on the animal type, grazing intensity, and frequency (Hobbs and Huenneke 1992), as well as grass productivity (Proulx and Mazumder 1998), climate, long-term exposure to herbivores (Milchunas et al. 1988), and the regional pool of potentially vulnerable plants (Zobel 1997). Prolonged overgrazing decreases species of high palatability for livestock animals and grassland productivity, and it negatively affects the sustainability of the whole grassland system, eventually restricting the development of animal husbandry, with resulting considerable economic loss (Wang et al. 2017). According to the intermediate disturbance hypothesis (Grimes 1973; Huston 1979) and the grazing optimization hypothesis (Hilbert et al. 1981), a moderate grazing intensity results in the grassland community displaying the greatest species diversity and aboveground net primary production (Sun et al. 2019).

The epidemiology of diseases in grasslands is affected by plant species biodiversity and the microenvironment, which in turn are affected by rainfall, air temperature, amount of sunshine, and wind. Loss of biodiversity can either increase or decrease disease transmission and severity (Keesing et al. 2010), but most research indicates that reduction of plant diversity, or corresponding increased 
density of a single host species, leads to increased pathogens and consequently more severe disease (Keesing et al. 2006, 2010; Rottstock et al. 2014). A reduction in plant richness can leave grassland ecosystems more vulnerable to encroachment by other plant species, potentially enhancing the spread of plant fungal disease (Knops et al. 1999). In contrast, an increase of species diversity can enrich the diversity of disease resistance and genetic backgrounds within the grassland community, providing both a natural isolation barrier between different species and reduced intraspecies niche competition, which together can reduce the risk of grassland disease outbreaks and epidemics (Keesing et al. 2006; Mitchell et al. 2002, 2003; Ostfeld and Keesing 2012). In addition, the phylogenetic structure of the host community can mediate the spread of pathogens, because the probability of a pathogen infecting two different host species decreases with increasing phylogenetic distance (Gilbert and Parker 2016). Grazing by large herbivores in the grassland ecosystem changes the canopy height and density (Bardgett and Wardle 2003), influencing humidity, temperature, and wind speed in the microenvironment, all factors strongly related with disease incidence and pathogen transmission (Gao et al. 2018). By removing pathogens by eating diseased plants, grazing animals can reduce the primary infection source and, therefore, control the occurrence of grassland diseases (Gray and Koch 2004; Skipp and Lambert 1984; Wennström and Ericson 1991). However, wounding of plants caused by grazing can increase infection by some pathogens and aggravate disease transmission (Daleo et al. 2009).

To date, most studies on grazing-grassland interactions have focused on the effects of grazing on grassland vegetation, ecosystem production, forage quality, and soil physicochemical properties (Bai et al. 2012; Shan et al. 2011). Although grazing management is known to cause changes in the interactions between plants, pathogens, and the environment (Bai et al. 2012; Daleo et al. 2009), there remains lack of knowledge on how disease occurrence and severity are altered through grazing effects on plant vegetation and microenvironment. To address this knowledge gap, we defined the effects of grazing on plant community composition, species richness, evenness, and the grassland microenvironment, which together act on the plant diseases through the changes caused by grazing in plant community structure and composition. Specifically, to do this, we first, determined the effects of grazing in the Hulunber grassland on the incidence and severity of plant diseases. Second, from this understanding, we evaluated the direct and/or indirect contribution of grazing on disease epidemiology in the grassland ecosystem from comparing the effects of six grazing intensities on population-level and community-level pathogen load based on data from 2015 to 2016.

\section{Materials and Methods}

Study site. The experimental site was located in the Hulunber Grassland Ecosystem Observation and Research Station located at Xiertala farm, the center of the Hulunber meadow steppe (latitude and longitude: $\mathrm{N} 49^{\circ} 19^{\prime} 21^{\prime \prime}$ to $49^{\circ} 20^{\prime} 10^{\prime \prime}$, E $119^{\circ} 56^{\prime} 31^{\prime \prime}$ to $119^{\circ} 57^{\prime}$ 51"; elevation: 666 to $680 \mathrm{~m}$ ), northeastern region of Inner Mongolia, China. The climate of this area is temperate semiarid continental, with an annual average of 110 frost-free days. The mean annual air temperature was between -5 and $-2^{\circ} \mathrm{C}$, with maximum monthly mean of $36.17^{\circ} \mathrm{C}$ in July and minimum of $-48.5^{\circ} \mathrm{C}$ in January. Mean annual precipitation ranges from 350 to $400 \mathrm{~mm}$, about $80 \%$ of which falls between July and September. Monthly average temperature and precipitation during 2010 to 2016 at the study site are shown in Supplementary Fig. S1. Compared with the long-term average, 2015 and 2016 were relatively dry years, especially during the growing season (Supplementary Fig. S1). Soil type was kastanozem according to the FAO/Unesco System of Soil Classification. The vegetation was characterized as a meadow steppe. The dominated grasses in the study site are Leymus chinensis and Stipa baicalensis. Accompanying plant species included Adenophora stenophylla, Artemisia dracunculus, Ar. tanacetifolia, Astragalus adsurgens, Carex duriuscula,
Heteropappus altaicus, Iris ventricosa, Pulsatilla turczaninovii, and Thalictrum petaloideum.

Experimental design. This grassland was subjected to six levels of cattle grazing intensity, in a randomized complete block design with three replicates for each block (Supplementary Fig. S2) from 2009. Six grazing intensities were set as follows: $0,0.23,0.34$, $0.46,0.69$, and $0.92 \mathrm{AU} / \mathrm{ha}$ (where $1 \mathrm{AU}=500 \mathrm{~kg}$ of adult cattle). Each plot was continuously grazed for 120 days annually during June to October, starting from 2009 (Yan et al. 2015). The grazing-free period was from October until the end of May the following year. Grazing cattle were kept in plots for $24 \mathrm{~h}$ per day and were supplied water from an outside source.

Vegetation characteristics investigation, microenvironment, and disease monitoring. Independently, five randomly picked $1 \times$ $1 \mathrm{~m}^{2}$ quadrats were examined monthly in each of the 18 grazing plots. To investigate vegetation characteristics in 2015 and 2016, an "early summer assessment" was made in June, and a "summer and early autumn assessment" was made in July and August. Within each quadrat, the number of total plant species, the density of each plant species, and the cover of each species were measured. Plant density was recorded as the individual number of each species, and the species richness and plant coverage of each species were recorded by visual estimation. A $1 \times 1-\mathrm{m}^{2}$ frame with 100 equally distributed grids was placed above the canopy to measure plant coverage, which was recorded as the individual plant species percentage in each quadrat. The species richness was calculated as total number of species in each quadrat. The plant species diversity was evaluated using the Shannon's evenness index (Shannon and Weaver 1949):

$$
\mathrm{H}=\sum_{1}^{\mathrm{k}} P_{i} \times \ln P_{i}
$$

where $k$ is the total species number of each quadrat, and $P_{i}$ is the proportion of all individual plants in the sample that belong to species $i$.

Precipitation and air temperature data were collected from an automatic meteorological station (MILOS 520, Vaisala, Finland) at 30-min intervals. Daily average grassland microenvironment temperature and humidity level in each grazing plot were recorded at $10 \mathrm{~cm}$ above the ground from May to September of 2015 and 2016 by using a Kestrel 4000 Pocket Weather Tracker (Boothwyn, PA).

From June to August in 2015 and 2016, the occurrence of disease was surveyed using five quadrat frames (each $1 \times 1 \mathrm{~m}$ ) in each of the 18 (each 5 ha) grazing plots, using a preselected " $\mathrm{X}$ " pattern (Madden and Hughes 1999). The distance for adjacent quadrats was at least $100 \mathrm{~m}$. We observed a total of 55 plant species across 18 plots in our experiment in 2015 and 2016. From this, 44 plant species were found to be infected with at least one fungal pathogen. The aboveground tissues (stems, leaves, and inflorescences) of all plants present per quadrat frame were visually examined. The incidence of disease on each plant species was recorded as the percentage of infected individuals per species in each quadrat frame. We recorded disease severity as the percentage of the plant tissue covered by fungal lesions, and the average disease severity of the 10 randomly selected plant individuals was calculated as the disease severity of each plant species. The community pathogen load (PL) was calculated as follows:

$$
\mathrm{PL}=\frac{\sum_{i=1}^{k} c_{i} s_{i}}{\sum_{i=1}^{k} c_{i}}
$$

where $k$ is the total number of plant host plant species, $c_{i}$ is the coverage of host plant species $i$, and $s_{i}$ is the disease severity index of host plant species $i$ (Liu et al. 2019; Mitchell et al. 2002).

Identification of pathogens. In 2014, prior to the start of this study, the diseases present on plant species were examined in the laboratory. We focused on the following pathogen groups: rusts, powdery mildews, downy mildews, smuts, and leaf spot diseases. To identify fungal pathogens in the experimental plots, we collected at 
least eight infected plants per plant species per each plot and confirmed pathogen identity at the species or genus level. The techniques used included examination by microscopy, fungal isolation into pure culture, polymerase chain reaction (PCR) examination, and pathogenicity testing. The identification and degree of pathogen specialization were based on the reports of diseases on plants present in this grassland (e.g., Bai et al. 2003; Chen et al. 1987; Guo and Liu 2005; Li and Nan 2015; Lu 2001; Nan and Li 1994; Qi et al. 1966; Wang and Zhuang 1998; Wang et al. 2003; Zhang et al. 2018; Zhao et al. 2015; Zhuang 2005, 2012). Identifications of the majority of leaf spot, rust, powdery mildew, downy mildew, and smut pathogens were confirmed by noting the morphological characteristics using an Olympus microscope (CX31, Tokyo, Japan). The leaf spot and rust pathogens on dominant species $L$. chinensis were identified based on their morphological and molecular characteristics. Plant tissues with lesions were surface sterilized with a wash in $75 \%$ ethanol for about $30 \mathrm{~s}$ followed by $1 \% \mathrm{NaClO}$ for about $1 \mathrm{~min}$, rinsed three times in sterile water, and placed in high-humidity conditions for 3 days. Pure cultures were obtained by picking off conidia using a flamed sterile needle, transferring them to plates containing potato dextrose agar (PDA) supplemented with antibiotics (39 g/liter of distilled water, Difco PDA, and $200 \mathrm{mg} / \mathrm{liter}$ of penicillin and streptomycin), and then subculturing onto PDA (Phookamsak et al. 2014). All Petri dishes were sealed with Parafilm (Pechiney Plastic Packaging, Chicago, IL) and incubated at $22^{\circ} \mathrm{C}$ without light in an incubator for about 4 weeks to obtain mycelial growth for DNA extraction (Chen et al. 2017). Fungal genomic DNA was extracted directly from mycelium using a UNIQ-10 fungal genomic DNA extraction kit (Sangon Biotech, Shanghai, China). DNA amplification was performed by PCR. The internal transcribed spacer region was amplified using primer pair ITS4 (5'-TCCTCCGCTTATTGATATGC-3') and ITS1 (5'-TCCGTAGGTGAACCTGCGG-3'). The partial small subunit nuclear rDNA (SSU gene) was amplified using primers NS1 and NS4 (White et al. 1990). PCR was performed in 50- $\mu$ l reaction mixtures, containing $1.5 \mu \mathrm{l}$ of each forward and reverse primers, $25 \mu \mathrm{l}$ of $2 \times$ Easy Taq PCR SuperMix (mixture of EasyTaq DNA Polymerase, dNTPs, and optimized buffer), $2.0 \mu 1$ of DNA template, and $20 \mu l$ of sterilized water (Phookamsak et al. 2013). The PCR thermal cycle protocol was as follows: $94^{\circ} \mathrm{C}$ for $3 \mathrm{~min} ; 40$ cycles of $94^{\circ} \mathrm{C}$ for 30 $\mathrm{s}, 55^{\circ} \mathrm{C}$ for $30 \mathrm{~s}$, and $72^{\circ} \mathrm{C}$ for $1 \mathrm{~min}$; and a final extension at $72^{\circ} \mathrm{C}$ for $10 \mathrm{~min}$. PCR products were sent for sequencing at Genewiz (Beijing, China). Sequences obtained were compared with those in the GenBank database using BLAST and with similar sequences in published articles.

Statistical analysis. Data analyses were performed using SPSS version 17.0 (SPSS, Chicago, IL). One-way ANOVA with Tukey's

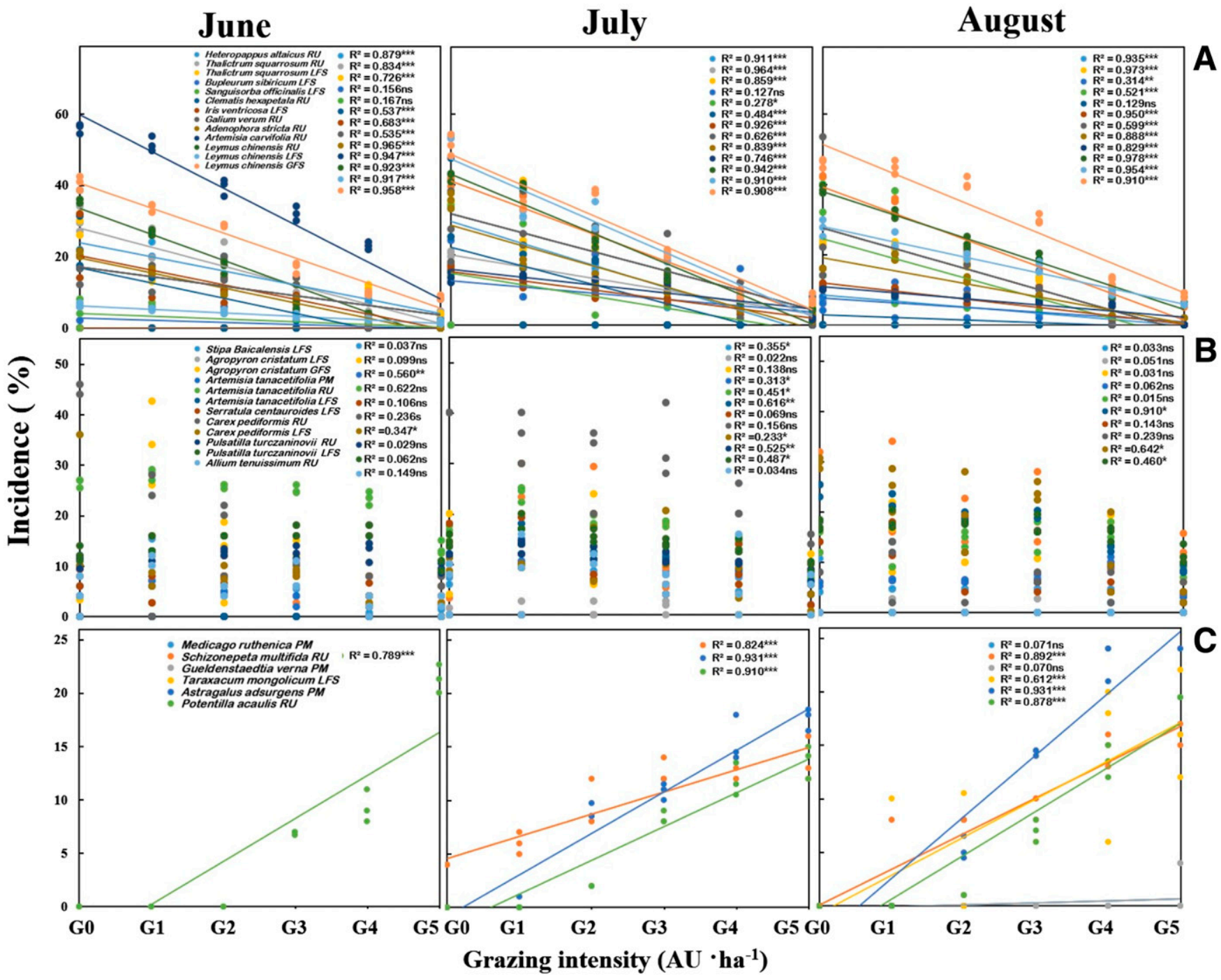

Fig. 1. Mean incidence of 33 plant diseases under six grazing intensities from June to August based on the 2-year (2015 and 2016) average. Incidences and grazing intensities showed a negative relationship (A), a positive relationship (C), or no significant relationship (B). Regression was estimated using a linear model with grazing intensity. The grazing intensities of $0,0.23,0.34,0.46,0.69$, and $0.92 \mathrm{AU} / \mathrm{ha}$ (where $1 \mathrm{AU}=500 \mathrm{~kg}$ of adult cattle) are represented by $\mathrm{G} 0, \mathrm{G} 1, \mathrm{G} 2, \mathrm{G} 3, \mathrm{G} 4$, and $\mathrm{G} 5$, respectively. Differences are reported as not significant (ns), $P>0.05 ;{ }^{*}=P<0.05 ;{ }^{* *}=P<0.01$; and ${ }^{* * *}=P<0.001$. Disease types are rust (RU), powdery mildew (PM), fungal leaf spot (LFS), and fungal gray leaf spot (GFS). 
tests $(P<0.05)$ was used to examine the effects of grazing on the microenvironment. Prior to ANOVA, data were checked for normality and homogeneity and were transformed whenever necessary, incidence $(\%)$ and disease severity index $(\%)$ data were normalized using an arcsine (y) transformation to meet the assumptions of the analysis (de la Cerda et al. 2007). The relationship among grazing intensity, plant density, plant coverage, plant species diversity, and the incidence of various diseases was analyzed using a linear model-repeated measures analysis.

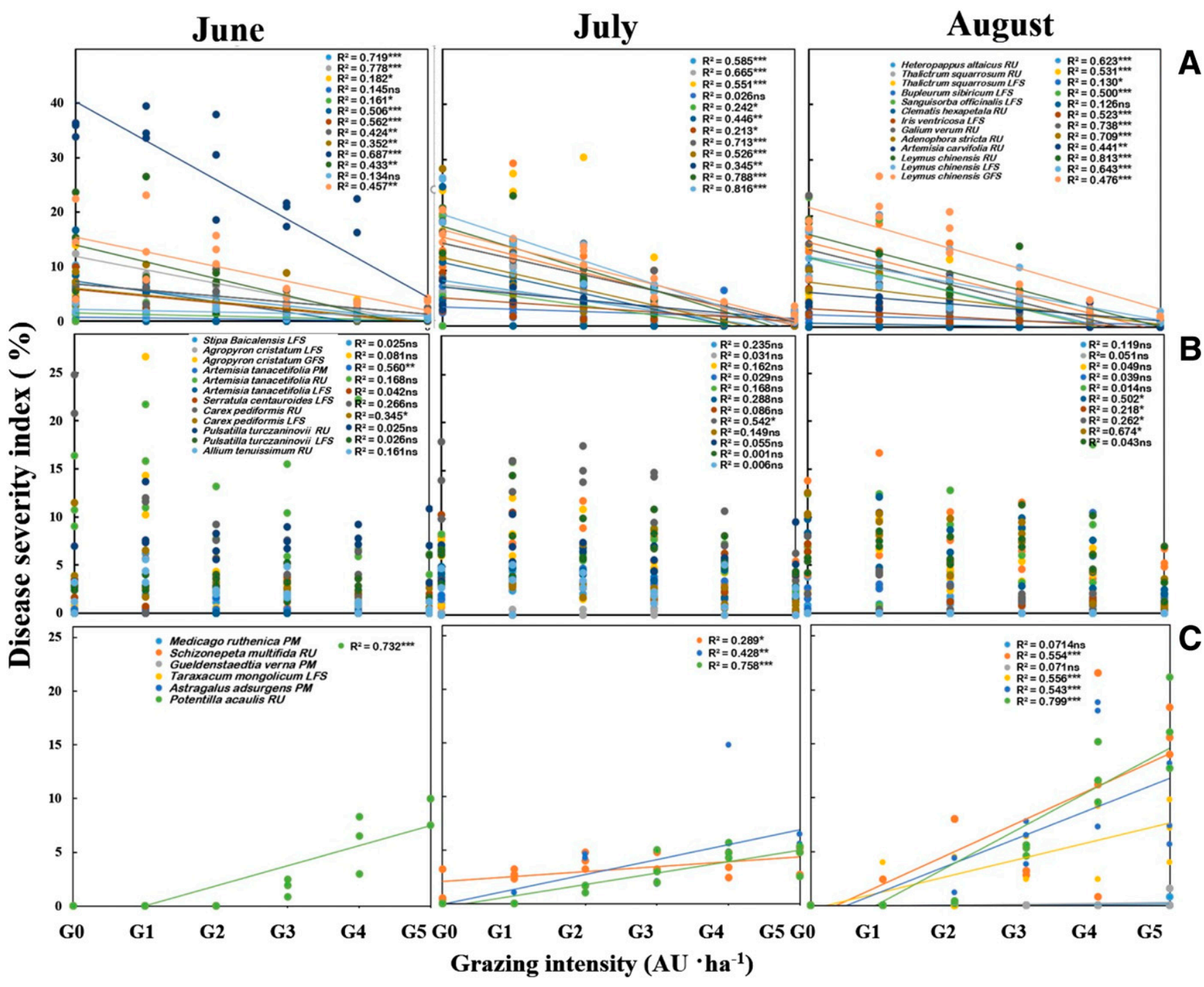

Fig. 2. Mean disease severity indices of 33 plant diseases under six grazing intensities from June to August based on the 2-year (2015 and 2016) average. Disease severity index and grazing intensities showed a negative relationship $(\mathbf{A})$, a positive relationship $(\mathbf{C})$, or no significant relationship (B). Regression was estimated using a linear model with grazing intensity. The grazing intensities of $0,0.23,0.34,0.46,0.69$, and $0.92 \mathrm{AU} / \mathrm{ha}$ (where $1 \mathrm{AU}=500 \mathrm{~kg}$ of adult cattle) are represented by G0, G1, G2, G3, G4, and G5, respectively. Differences are reported as not significant (ns), $P>0.05 ;{ }^{*}=P<0.05 ;{ }^{* *}=P<0.01$; and ${ }^{* * *}=P<0.001$. Disease types are rust (RU), powdery mildew (PM), fungal leaf spot (LFS), and fungal gray leaf spot (GFS).

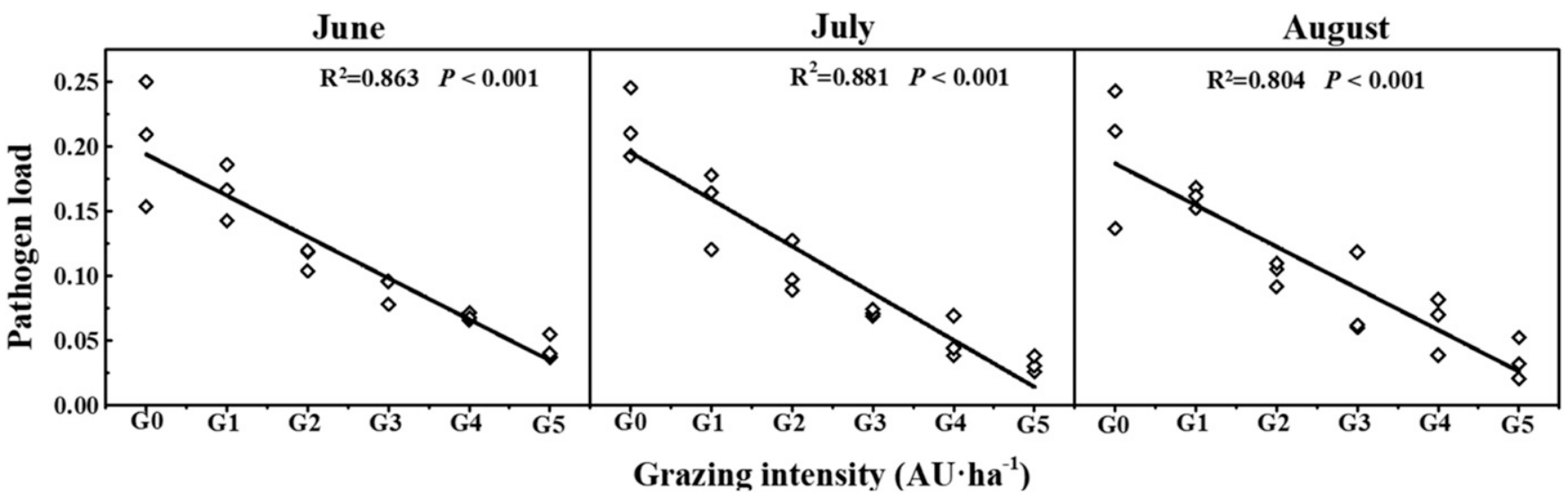

Fig. 3. Linear regression analysis between community pathogen load and grazing intensity from June to August based on 2-year (2015 and 2016) average. The grazing intensities of $0,0.23,0.34,0.46,0.69$, and $0.92 \mathrm{AU} / \mathrm{ha}$ (where $1 \mathrm{AU}=500 \mathrm{~kg}$ of adult cattle) are represented by G0, G1, G2, G3, G4, and G5, respectively. 
Based on the linear regression and redundancy analysis (RDA) results, we estimated the strength of direct and indirect relationships among the considered variables, including grazing intensity, seasonal changes, host density, host coverage, plant species diversity, microenvironment, and the community pathogen load. To ensure the linear models were appropriate, the bivariate relationships between variables were first checked. Structural equation modeling (SEM) was used to identify potential causal linkages between the different factors and community pathogen load. Several SEM models based on the known effects and potential relationships among the factors and plant diseases were constructed. SEM steps were carried out using AMOS 25.0 (Amos Development, Greene, ME).

\section{Results}

Effects of grazing on grassland vegetation characteristics and microenvironment. The density and coverage of the plant species were significantly affected by grazing intensity (Supplementary Figs. S3 and S4). Compared with the nongrazing treatment, grazing decreased the total density and coverage of all the plant species by an average of 59.1 and $64.7 \%$, respectively. The density (Supplementary Fig. S3a) and coverage (Supplementary Fig. S4a) of Adenophora stricta, Artemisia carvifolia, Bromus inermis, Bupleurum sibiricum, Clematis hexapetala, Galium verum, $H$. altaicus, I. ventricosa, L. chinensis, Sanguisorba officinalis, Thalictrum squarrosum, and Vicia tenuifolia significantly decreased $(P<0.05)$ with increased grazing intensity. The density (Supplementary Fig. S3b) and coverage (Supplementary Fig. S4b) of Agropyron cristatum, Allium tenuissimum, Ar. tanacetifolia, Carex pediformis, Poa annua, P. turczaninovii, Serratula centauroides, and Stipa baicalensis showed no significant relationships $(P>0.05)$ with the increase of grazing intensity. The density (Supplementary Fig. S3c) and coverage (Supplementary Fig. S4c) of Artemisia frigia, As. adsurgens, C. duriuscula, Gueldenstaedtia verna, Koeleria cristata, Medicago ruthenica, Oxytropis myriophylla, Potentilla acaulis, Schizonepeta multifida, and Taraxacum mongolicum increased as grazing intensity increased.

There were significant differences in plant species diversity between the different grazing intensities from June to August (Supplementary Fig. S5). When correlations were made between plant species diversity (expressed as Shannon's evenness index) and grazing intensity for each of the months June, July, and August (averaged across the 2 years of 2015 and 2016), typical bell-shaped curves were established. These could be described by an upwardly concave significant quadratic equation, in which grazing explained 74.2, 78.3, and $51.9 \%$ of the variances of June, July, and August, respectively (Supplementary Fig. S5).

Cattle grazing at each grazing intensity resulted in reduced humidity and increased temperature, in comparison with the nongrazed control treatment plots (Supplementary Fig. S6).

Pathogen community. In total, 87 plant/pathogen combinations were found across the grazed plots, including 32 rusts, 13 powdery mildews, three downy mildews, two smuts, and 37 fungal leaf spot diseases (Supplementary Tables S1 and S2). Altogether, the pathogens responsible for 50 different diseases were identified to the species level, and pathogens for 19 different diseases were keyed out to genus level. The pathogens of the remaining 18 diseases could not be identified. Leaf spots, rusts, and powdery mildews were the dominant pathogen groups in the grassland community. In our surveys, we found that the vast majority of pathogens were specialists at the plant species, genus, or family level, except for Puccinia elymi (hosts: L. chinensis and Ag. cristatum) and Septoria nodorum (hosts: L. chinensis, Ag. cristatum, B. inermis, and Stipa baicalensis) (Supplementary Tables S1 and S2).

Effect of grazing on grassland plant diseases. The incidence of some plant species like Ad. stricta, Ar. carvifolia, and B. inermis decreased significantly $(P<0.05)$ with increased grazing intensity across the growing season from June to August (Fig. 1A). However, in contrast, the incidence of plant species like Ar. frigia, As. adsurgens, and $C$. duriuscula increased significantly $(P<0.05)$ with increasing grazing intensity (Fig. 1C). Compared with nongrazing control treatment, grazing reduced the incidence of Ad. stricta and some others by 16.3 to $82.4 \%$, whereas the incidence of plant species such as Ar. frigia As. adsurgens, and C. duriuscula increased by 129.1 to $752.1 \%$.

The disease severity index of leaf spots on some plant species like $A d$. stricta, Ar. carvifolia, and B. inermis decreased with the increase of grazing intensity (Fig. 2A). In contrast, the disease severity indices of pathogen groups (rusts and powdery mildew) on plant species such as Ar. frigia, As. adsurgens, and C. duriuscula increased with increase of grazing intensity during the growing season (Fig. 2C). Grazing intensities and seasonal changes significantly $(P<0.05)$ affected the incidence and disease severity index of grasses such as Ar. carvifolia and B. inermis and small herbs. The community pathogen loads of each month, from June to August based on 2-year (2015 and 2016) average, showed negative linear relationships with grazing, explaining over $80 \%$ of the variances of these 3 months (Fig. 3).

Factors influencing grassland plant diseases. RDA showed that the first and second axis of RDA explained 89.7 and $24.8 \%$ of the variance, respectively. Disease incidence and disease severity index were negatively related with species grazing intensity, Shannon's evenness index, species richness, and microtemperature but positively related to microhumidity, seasonal changes, plant density, and plant coverage. The effects of plant density, plant coverage, and grazing intensity on disease incidence and disease severity index were significant, explaining $34.0,28.7$, and $27.9 \%$ of the total variation in disease occurrence, respectively (Fig. 4).

The final model (SEM) adequately fitted the data $\left(\chi^{2}=166.404\right.$, Df $=12, P=0.259$, goodness of fit index $=0.805)$ and explained $71.0 \%$ of the variance of pathogen load (marginal $R^{2}=0.710$ ). In the final model, grazing significantly negatively $(P<0.001)$ affected the pathogen load, whereas seasonal changes significantly positively $(P<0.01)$ affected the pathogen load directly. Grazing significantly negatively $(P<0.01)$ affected pathogen load as it negatively $(P<$ $0.001)$ affected host coverage. Seasonal changes significantly positively $(P<0.05)$ affected pathogen load but significantly negatively $(P<0.001)$ affected host density. In addition, grazing also negatively affected microhumidity by changing host coverage and density and also significantly reduced $(P<0.05)$ pathogen load (Fig. 5).

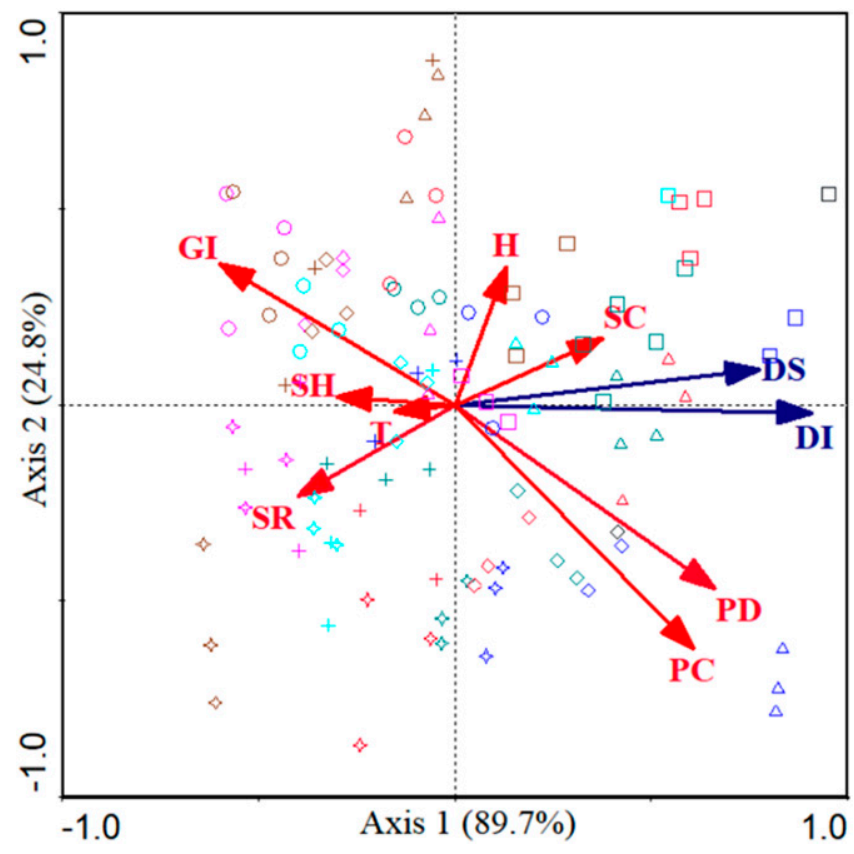

Fig. 4. Redundancy analysis showing the correlation of grazing intensity (GI), plant density (PD), plant coverage (PC), species richness (SR), species Shannon's evenness index $(\mathrm{SH})$, seasonal changes $(\mathrm{SC})$, microhumidity $(\mathrm{H})$, and microtemperature (T) with disease incidence (DI) and severity (DS) based on the 2year (2015 and 2016) data. Direction of arrow indicates the parameters associated with diseases, and the length of the arrow indicates the magnitude of the association. 


\section{Discussion}

In this study of the effects of grazing intensity on community composition, microenvironment, and plant disease in the Hulunber meadow steppe, we found that grazing decreased disease prevalence on palatable species such as Ad. stricta, Ar. carvifolia, B. inermis, and $L$. chinensis but increased disease in some small or coarse herbs such as Ar. frigia, As. adsurgens, and $C$. duriuscula. However, overall, grazing more generally decreased the pathogen load of the host community when considered as a single entity. Additionally, we found that seasonal changes also significantly affected disease prevalence in the Hulunber meadow steppe, such that the pathogen load of the host community significantly increased over time. It was also evident that grazing was far more important and outweighed seasonal changes in terms of ability to alter plant diseases in the Hulunber meadow steppe. In addition, although the epidemiology of plant diseases, both directly and indirectly, was altered through changing grassland community structure and the microenvironment consequent from grazing, the changes in grassland community structure were more important than shifts in microenvironment in altering community pathogen load.

The direct effects of grazing livestock on grassland include ingestion, trampling, and excretion (Zhang et al. 2019). The most obvious contributions of grazing by herbivores to the grassland ecosystem are changes in height and coverage of the canopy (Bakker et al. 2006; Bardgett and Wardle 2003). This effect always depends on the palatability and edibility of forages (Ericson and Wennström 1997). In the Hulunber meadow steppe, the incidence of palatable species such as Ad. stricta, Ar. carvifolia, B. inermis, and L. chinensis was lowest in treatments of greatest grazing intensity due to their high palatability; in contrast, the incidence of small or coarse herbs such as Ar. frigia, As. adsurgens, and C. duriuscula was greatest in treatments of greatest grazing intensity because coarse herbs are much less palatable, with livestock generally avoiding ingesting them. Previous grazing studies carried out at this site have highlighted the selective foraging of cattle, in which they preferentially eat the most palatable plants (Yan et al. 2015). This can be advantageous when preferential grazing of high-quality, highly palatable forage species such as $L$. chinensis occurs, because grazing removes disease-infested plant tissues (Daleo et al. 2009; Skipp and Lambert 1984), not only utilizing infested forage as feed but at the same time lowering the inoculum potential of fungal pathogens of these plant species (Ericson and Wennström 1997), including reducing their ability to overwinter and initiate epidemics in subsequent years. That the incidence and disease index of palatable forages tended to decrease proportionally in relation to corresponding increase of grazing intensity highlights the potential to manipulate grazing to varying extents to manage different disease severity situations.

It was widely accepted that herbivores grazing can also facilitate disease spread by causing wounds on plant tissue through ingesting and trampling (Daleo et al. 2009; Fraedrich et al. 2008; Wennström and Ericson 1991). However, this can be more than offset when grazing reduces community pathogen load from animals ingesting palatable and edible forages (Daleo et al. 2009; Skipp and Lambert 1984), as found in the present study. However, the situation in the heaviest grazing intensity treatment was quite contrasting, leaving uneaten small herbs with more space to grow, but at the same time making conditions more conducive to pathogen invasion, such as the high levels of powdery mildew observed under the heaviest grazing.

In contrast to grazing, seasonal changes increased the pathogen load over time, despite such effects being "weaker" than from grazing. Seasonal changes influenced the disease types and the order in which different diseases appeared. In the current study, although leaf

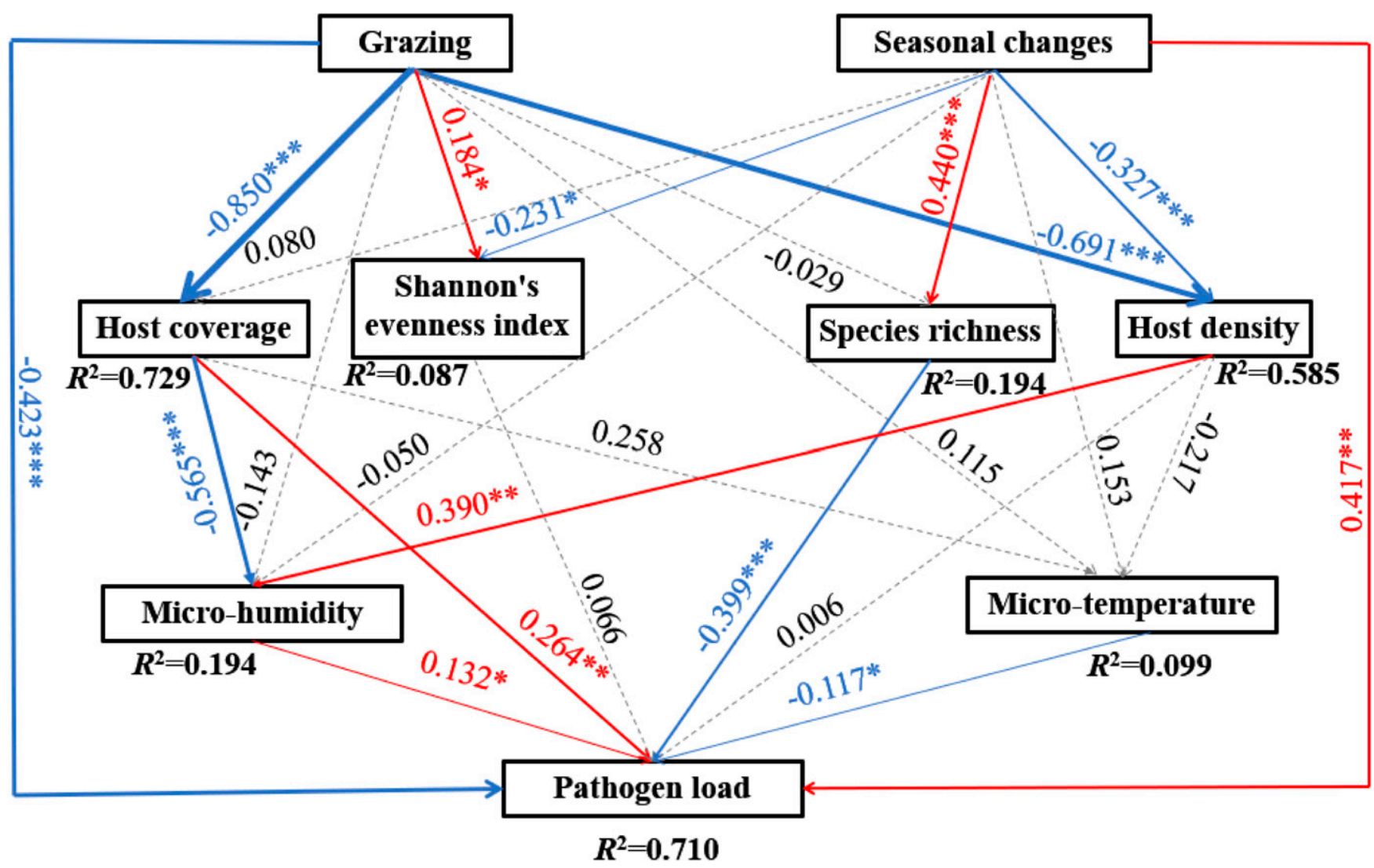

Fig. 5. The final model results of structural equation modeling analysis for grazing intensity, seasonal changes, vegetation characteristics, and microenvironmental factors on pathogen load in 2015 and 2016. Red (lighter) arrows indicate evidence for positive relationships, blue (darker) arrows indicate evidence for negative relationships, and gray dashed arrows indicate insufficient statistical evidence for path coefficients $(P>0.05)$. Width of the arrows shows the strength of the causal relationship, and the numbers adjacent to arrows are standardized path coefficients, which reflect the extent of the relationship. Asterisks indicate statistical significance ${ }^{* \star *}, P<0.001 ;{ }^{* *}, P<0.01 ;$ and ${ }^{*}$, $P<0.05)$. The proportion of variance explained $\left(R^{2}\right)$ appears alongside each response variable in the model. The final model adequately fitted the data: $\chi^{2}=166.404, \mathrm{Df}=$ $12, P=0.259$, and goodness of fit index $=0.805$. 
spots and rusts were most common during the grazing period, rusts were favored by periods of higher humidity (Gao et al. 2018), presented first, and peaked in July when temperatures were considered "moderate". In contrast, leaf spots and powdery mildews presented later, when humidity was lower, and peaked in August. Lower temperature conditions favor buildup of downy mildew epidemics (Thind et al. 2004); hence, it was the last disease to present. Over time, the incidence of leaf spots increased gradually until they surpassed rusts as the most prevalent disease symptom.

The ingestion, trampling, and excretion of grazing herbivores affected the relationships in terms of the different pathogens, the host plants, and the microenvironment, thus indirectly producing a range of different ecological outcomes in terms of grassland diseases (Daleo et al. 2009; Li and Nan 2015). In our study, changes in community pathogen load in relation to changes in grazing intensity and seasonal conditions were mediated by these above-mentioned indirect effects. Lower host abundance and/or changes in canopy microenvironment have long been considered a significant reason why herbivore grazing reduces the level of diseases in grasslands (Bowers and Sacchi 1991; Hatcher and Paul 2000; Skipp and Lambert 1984; Wennström and Ericson 1991). Previous studies on the indirect effects of grazing on grassland diseases have identified effects of changes in plant community structure (e.g., host density, coverage, and species diversity) as important factors influencing disease prevalence (Keesing et al. 2006; Mitchell et al. 2002; Rottstock et al. 2014).

Our study confirmed that grazing significantly affects the richness of plant community species in grasslands, as also demonstrated by others such as Hou and Yang (2006). According to the intermediate disturbance hypothesis (Grimes 1973; Huston 1979) and grazing optimization hypothesis (Hilbert et al. 1981), the richness of plant species and aboveground net primary production are greatest at an intermediate grazing intensity (Knapp et al. 2012). Ecological theory predicts that high host richness is more likely to decrease than increase the overall disease risk (Keesing et al. 2006). When faced with a genetically diverse group of pathogens, host monocultures are more susceptible to disease(s) compared with when there is diversity of host species (Ostfeld and Keesing 2012). This parallels our findings, in which host species richness in G1 and G2 treatments was significantly higher, but the incidence and disease severity index were lower, than that in nongrazed treatments. Such disease reduction accompanies increased genetic diversity arising from specific traits of the genotypes (Mundt et al. 2011; Zhu et al. 2000). Maintaining high plant species richness, as can be obtained by suitable grazing, offers significant opportunities for effective control of at least some diseases in natural grasslands, depending on pathogen specialization and host-species identities. In particular, reduced disease risk with increasing host diversity typically occurs when pathogen transmission is frequency dependent (Keesing et al. 2006). In contrast, loss of plant diversity frequently increases the possibility of disease epidemics (Keesing et al. 2010). In the current study, the model (SEM) also suggested that host species richness has a negative relationship with community pathogen load.

The effect of grazing on plant density largely depends on the magnitude of palatable species, because these were preferentially grazed relative to species of poor palatability or plants with decumbent growth (Yan et al. 2015). Our findings showed a substantial decrease in the density of palatable and some edible forages with increasing grazing intensity, whereas the density of small or coarse herbs increased at the same time. Together, these are in agreement with a number of previous studies showing that as grazing intensity rises, the number and biomass of high-palatability species decrease, whereas species of poor palatability and resistance to trampling increase (Dong et al. 2007), leading to altered species composition and canopy traits (Belsky 1986; Christiansen and Svejcar 1988; Liu et al. 2002; Noy-Meir 1993). We found that the rapid increases in some small or coarse herbs were mainly a consequence their poor palatability, as reported earlier by Yan et al. (2015). Selective grazing away from small or coarse herbs would be one of the factors why the incidence of powdery mildew and rusts on them increased with increasing grazing intensity in our study. Further, spread of some pathogens among grasslands can be facilitated by the movement of herbivores, particularly mechanical damage caused by grazing or trampling (Crawley 1983). In addition, meteorological factors also play a critical role in the status of host species composition and occurrence of diseases. For example, a closed canopy cover in plant communities may provide a favorable environment for pathogen development via increased humidity for spore germination (Chapin 2003) and via leaf wetness (Bradley et al. 2003). Concomitant changes in microenvironment also affect pathogen presence and overall infection in plant communities (Mulder et al. 2008).

In a sense, the effects of species richness on pathogen transmission are an extension of the effects of pathogen transmission on genetic diversity within species (Ostfeld and Keesing 2012). Further studies involving host and pathogen sets of varying genetic distance could be enlightening to further explain the complex pathogen-hostenvironment interactions occurring within grassland systems.

To our knowledge, this study is the first to examine how grazing intensity affects the disease risk by its effects on plant abundance and microenvironment factors in a grazed grassland ecosystem. Our results demonstrate that grazing plays a major role in the disease occurrence in Hulunber meadow steppe grasslands and that grazing alters epidemiology of plant diseases by shifting the plant community structure and altering its microhumidity. In influencing disease occurrence and abundance, the direct effects of grazing intensity were more important than indirect effects of shifts in grassland community composition. The present study expands our knowledge of the relationship between grazing and grassland disease, quantificationally clarifying the direct and indirect effects of grazing on grassland disease in the Hulunber meadow steppe.

\section{Acknowledgments}

We thank Hulunber Grassland Ecosystem Research Station for providing the experimental plots, facilities, and meteorological data. We thank Chao Xia, Jianxiao Zhu, and Shanshan Song for their assistance in the revision of manuscript and statistical analysis.

\section{Literature Cited}

Altesor, A., Oesterheld, M., Leoni, E., Lezama, F., and Rodríguez, C. 2005. Effect of grazing on community structure and productivity of a Uruguayan grassland. Plant Ecol. 179:83-91.

Asner, G. P., Elmore, A. J., Olander, L. P., Martin, R. E., and Harris, A. T. 2004 Grazing systems, ecosystems responses, and global changes. Annu. Rev. Environ. Resour. 29:261-299.

Bai, J. K., Lv, G. Z., Sun, J. D., Li, W. C., Zhou, Y. L., Yu, L., Liang, J. Y., and Luo, F. X. 2003. Sghaeropsidales Ascochyta Septoria. Vol. 17. Flora Fungorum Sinicorum. Science Press, Beijing, China.

Bai, Y., Wu, J., Clark, C. M., Pan, Q., Zhang, L., Chen, S., Wang, Q., and Han, X. 2012. Grazing alters ecosystem functioning and C: N: P stoichiometry of grasslands along a regional precipitation gradient. J. Appl. Ecol. 49: 1204-1215.

Bakker, E. S., Ritchie, M. E., Olff, H., Milchunas, D. G., and Knops, J. M. H. 2006 Herbivore impact on grassland plant diversity depends on habitat productivity and herbivore size. Ecol. Lett. 9:780-788.

Bardgett, R. D., and Wardle, D. A. 2003. Herbivore-mediated linkages between aboveground and belowground communities. Ecology 84:2258-2268.

Belsky, A. J. 1986. Does herbivory benefit plants: A review of the evidence. Am. Nat. 127:870-892.

Bowers, M. A., and Sacchi, C. F. 1991. Fungal mediation of a plant-herbivore interaction in an early successional plant community. Ecology 72:1032-1037.

Bradley, D. J., Gilbert, G. S., and Parker, I. M. 2003. Susceptibility of clover species to fungal infection: The interaction of leaf surface traits and environment. Am. J. Bot. 90:857-864.

Briske, D. D., Fuhlendorf, S. D., and Smeins, F. E. 2003. Vegetation dynamics on rangelands: A critique of the current paradigms. J. Appl. Ecol. 40:601-614.

Chapin, F. S. 2003. Effects of plant traits on ecosystem and regional processes: A conceptual framework for predicting the consequences of global change. Ann. Bot. (London) 91:455-463.

Chen, G. Q., Yu, Y. N., Zheng, R. Y., Han, S. J., and Lai, Y. Q. 1987. Erysiphales Vol. 1. Flora Fungorum Sinicorum. Science Press, Beijing, China.

Chen, T., Zhang, Y. W., Christensen, M., Li, C. H., Hou, F. J., and Nan, Z. B. 2017. Grazing intensity affects communities of culturable root-associated fungi in a semiarid grassland of northwest China. Land Degrad. Dev. 29:361-373.

Christiansen, S. O., and Svejcar, T. 1988. Grazing effects on shoot and root dynamics and above- and below-ground non-structural carbohydrate in Caucasian bluestem. Grass Forage Sci. 43:375-435. 
Crawley, M. J. 1983. Herbivory: The Dynamics of Animal-Plant Interactions. Blackwell Scientific Publications, Oxford, U.K.

Daleo, P., Silliman, B., Alberti, J., Escapa, M., Canepuccia, A., Peña, N., and Iribarne, O. 2009. Grazer facilitation of fungal infection and the control of plant growth in south-western Atlantic salt marshes. J. Ecol. 97:781-787.

de la Cerda, K. A., Douhan, G. W., and Wong, F. P. 2007. Discovery and characterization of Waitea circinata var. circinata affecting annual bluegrass from the western United States. Plant Dis. 91:791-797.

Dong, Q. M., Zhao, X. Q., and Ma, Y. S. 2007. Study on community quantity character in Alpine mixed-sown grassland under different grazing intensities. Acta Agrestia Sin. 15:394 (In Chinese with English abstract).

Ericson, L., and Wennström, A. 1997. The effect of herbivory on the interaction between the clonal plant Trientalis europaea and its smut fungus Urocystis trientalis. Oikos 80:107-111.

Fisher, M. C., Henk, D. A., Briggs, C. J., Brownstein, J. S., Madoff, L. C., McCraw, S. L., and Gurr, S. J. 2012. Emerging fungal threats to animal, plant and ecosystem health. Nature 484:186-194.

Fraedrich, S. W., Harrington, T. C., Rabaglia, R. J., Ulysen, M. D., Mayfield, A. E., Hanula, J. I., Eickwort, J. M., and Miller, D. R. 2008. A fungal symbiont of the redbay Ambrosia beetle causes a lethal wilt in redbay and other Laureaceae in the southeastern United States. Plant Dis. 92:215-224.

Gao, P., Duan, T. Y., Nan, Z. B., Christensen, M. J., Liu, Q. T., Meng, F. J., and Huang, J. F. 2018. The influence of irrigation frequency on the occurrence of rust disease (Melampsora apocuni) and determination of the optimum irrigation regime in organic Apocynum venetum production. Agric. Water Manage. 205:81-89.

Gilbert, G. S., and Parker, I. M. 2016. The evolutionary ecology of plant disease: A phylogenetic perspective. Annu. Rev. Phytopathol. 54:549-578.

Gray, F. A., and Koch, D. W. 2004. Influence of late season harvesting, fall grazing, and fungicide treatment on verticillium wilt incidence, plant density, and forage yield of alfalfa. Plant Dis. 88:811-816.

Grimes, J. P. 1973. Control of species density in herbaceous vegetation. J. Environ. Manage. 1:151-167.

Guo, L. Y., and Liu, X. J. 2005. Cercospora. Vol. 20. Flora Fungorum Sinicorum. Science Press, Beijing, China.

Hatcher, P. E., and Paul, N. D. 2000. Beetle grazing reduces natural infection of Rumex obtusifolius by fungal pathogens. New Phytol. 146:325-333.

Hilbert, D. W., Swift, D. M., Detling, J. K., and Dyer, M. I. 1981. Relative growth rates and the grazing optimization hypothesis. Oecologia 51:14-18.

Hobbs, R. J., and Huenneke, L. F. 1992. Disturbance, diversity, and invasion: Implications for conservation. Conserv. Biol. 6:324-337.

Hou, F. J., and Yang, Z. Y. 2006. Effects of grazing of livestock on grassland. Acta Ecol. Sin. 26:244-264 (In Chinese with English abstract).

Huston, M. A. 1979. General hypothesis of species diversity. Am. Nat. 113: 81-101.

Keesing, F., Belden, L. K., Daszak, P., Dobson, A., Harvell, C. D., Holt, R. D., Hudson, P., Jolles, A., Jones, K. E., Mitchell, C. E., Myers, S. S., Bogich, T., and Ostfeld, R. S. 2010. Impacts of biodiversity on the emergence and transmission of infectious diseases. Nature 468:647-652.

Keesing, F., Holt, R. D., and Ostfeld, R. S. 2006. Effects of species diversity on disease risk. Ecol. Lett. 9:485-498.

Knapp, A. K., Hoover, D. L., Blair, J. M., Buis, G., Burkepile, D. E., Chamberlain, A., Collins, S. L., Fynn, R. W. S., Kirkman, K. P., Smith, M. D., Blake, D., Govender, N., O'Neal, P., Schreck, T., and Zinn, A. 2012. A test of two mechanisms proposed to optimize grassland aboveground primary productivity in response to grazing. J. Plant Ecol. 5:357-365.

Knops, J. M. H., Tilman, D., Haddad, N. M., Naeem, S., Mitchell, C. E., Haarstad, J., Ritchie, M. E., Howe, K. M., Reich, P. B., Siemann, E., and Groth, J. 1999. Effects of plant species richness on invasion dynamics, disease outbreaks, insect abundances and diversity. Ecol. Lett. 2:286-293.

Kraaij, T., and Milton, S. J. 2006. Vegetation changes (1995-2004) in semi-arid Karoo shrubland, South Africa: Effects of rainfall, wild herbivores and change in land use. J. Arid Environ. 64:174-192.

Li, Y. Z., and Nan, Z. B. 2015. The Methods of Diagnose, Investigation and Loss Evaluation for Forage Diseases. Phoenix Press, Nanjing, China.

Liu, R. C. 2008. Effect of grazing and fencing on disease of grassland plants. M.S. thesis. Lanzhou University, Lanzhou, China (In Chinese with English abstract).

Liu, X., Ma, Z., Cadotte, M. W., Chen, F., He, J., and Zhou, S. 2019. Warming affects foliar fungal diseases more than precipitation in a Tibetan alpine meadow. New Phytol. 221:1574-1584.

Liu, Y., Wang, D. L., Wang, X., Ba, L., and Sun, W. 2002. The effect of grazing intensity on vegetation characteristics in Leymus chinensis grassland. Acta Agrestia Sin. 11:22-28 (In Chinese with English abstract).

Liu, Y., Zhang, Y. W., Nan, Z. B., and Duan, T. Y. 2016. Progress of research into the effects of native grassland management practices on plant disease. Acta Ecol. Sin. 36:4211-4220 (In Chinese with English abstract).

Lu, J. Y. 2001. Plant Pathogenic Mycology. China Agriculture Press, Beijing, China

Madden, L. V., and Hughes, G. 1999. Sampling for plant disease incidence. Phytopathology 89:1088-1103.

Marty, J. T. 2005. Effects of cattle grazing on diversity in ephemeral wetlands. Conserv. Biol. 19:1626-1632.
Milchunas, D. G., Sala, O. E., and Lauenroth, W. K. 1988. A generalized model of the effects of grazing by large herbivores on grassland community structure. Am. Nat. 132:87-106.

Mitchell, C. E., Reich, P. B., Tilman, D., and Groth, J. V. 2003. Effects of elevated $\mathrm{CO}_{2}$, nitrogen deposition, and decreased species diversity on foliar fungal plant disease. Glob. Change Biol. 9:438-451.

Mitchell, C. E., Tilman, D., and Groth, J. V. 2002. Effect of grassland plant species diversity, abundance, and composition on foliar fungal disease. Ecology 83 1713-1726.

Mulder, C. P. H., Roy, B. A., and Güsewell, S. 2008. Herbivores and pathogens on Alnus viridis subsp. fruticosa in interior Alaska: Effects of leaf, tree, and neighbour characteristics on damage levels. Botany 86:408-421.

Mundt, C. C., Sackett, K. E., and Wallace, L. D. 2011. Landscape heterogeneity and disease spread: Experimental approaches with a plant pathogen. Ecol. Appl. 21:321-328.

Nan, Z. B., and Li, C. J. 1994. Fungal diseases of pasture plants recorded in China-A check list. Pratacult. Sci. 11 (in Chinese with English summary).

Nan, Z. B., and Li, C. J. 2003. Forage and turfgrass disease in China and their control. Pages 3-10 in: Forage and Turfgrass Pathological Research in China. Z. B. Nan and C. J. Li, eds. Ocean Press, Beijing, China.

Northup, B., Brown, J., and Holt, J. 2013. Grazing impacts on the spatial distribution of soil microbial of soil microbial community to livestock grazing in the Tibetan alpine grassland. Glob. Change Biol. 19:637-648.

Noy-Meir, I. 1993. Compensating growth of grazed plants and its relevance to the use of rangelands. Ecol. Appl. 3:32-34.

Ostfeld, R. S., and Keesing, F. 2012. Effects of host diversity on infectious disease. Annu. Rev. Ecol. Evol. Syst. 43:157-182.

Phookamsak, R., Liu, J. K., Chukeatirote, E., McKenzie, E. H. C., and Hyde, K. D 2013. Phylogeny and morphology of Leptosphaerulina saccharicola sp. nov. and Pleosphaerulina oryzae and relationships with Pithomyces. Cryptogam., Mycol. 34:303-319.

Phookamsak, R., Liu, J. K., McKenzie, E. H. C., Manamgoda, D. S., Ariyawansa, H., Thambugala, K. M., Dai, D., Camporesi, E., Chukeatirote, E., Wijayawardene, N. N., Bahkali, A. H., Mortimer, P. E., Xu, J., and Hyde, K. D. 2014. Revision of Phaeosphaeriaceae. Fungal Divers. 68:159-238.

Proulx, M., and Mazumder, A. 1998. Reversal of grazing impact on plant species richness in nutrient-poor vs. nutrient-rich ecosystems. Ecology 79:2581-2592.

Qi, P. K., Bai, J. K., and Zhu, G. X. 1966. Jilin Province Cultivated Plant Fungi Disease. Science Press, Beijing, China.

Rottstock, T., Joshi, J., Kummer, V., and Fischer, M. 2014. Higher plant diversity promotes higher diversity of fungal pathogens, while it decreases pathogen infection per plant. Ecology 95:1907-1917.

Shan, Y. M., Chen, D. M., Guan, X. X., Zheng, S. X., Chen, H. J., Wang, M. J., and Bai, Y. F. 2011. Seasonally dependent impacts of grazing on soil nitrogen mineralization and linkages to ecosystem functioning in Inner Mongolia grassland. Soil Biol. Biochem. 43:1943-1954.

Shannon, C. E., and Weaver, W. 1949. Page 117 in: The Mathematical Theory of Communication. University of Illinois Press, Urbana, IL.

Skipp, R. A., and Lambert, M. G. 1984. Damage to white clover foliage in grazed pastures caused by fungi and other organisms. N. Zeal. J. Agric. Res. 27: 313-320.

Sun, J., Zhan, T., Liu, M., Zhang, Z., Wang, Y., Liu, S., Wu, G., Liu, G., and Tsunekawa, A. 2019. Verification of the biomass transfer hypothesis under moderate grazing across the Tibetan plateau: A meta-analysis. Plant Soil. doi: 10.1007/s11104-019-04380-8. doi.org/10.1007/s11104-019-04380-8

Thind, T. S., Arora, J. K., Mohan, C., and Raj, P. 2004. Epidemiology of powdery mildew, downy mildew and anthracnose diseases of grapevine. Pages 621-638 in: Diseases of Fruits and Vegetables. Vol. I. S. A. M. H. Naqvi, ed. Springer, Dordrecht, the Netherlands.

Wang, Y. Z., Wei, S. X., and Zhuang, J. Y. 2003. Uredinales (II). Vol. 19. Flora Fungorum Sinicorum. Science Press, Beijing, China.

Wang, Y. Z., and Zhuang, J. Y. 1998. Uredinales (I). Vol. 10. Flora Fungorum Sinicorum. Science Press, Beijing, China.

Wang, Z., Deng, X., Song, W., Li, Z., and Chen, J. 2017. What is the main cause of grassland degradation? A case study of grassland ecosystem service in the middle-south Inner Mongolia. Catena 150:100-107.

Wang, Z. W., Jiao, S. Y., Han, G. D., Zhao, M. L., Ding, H. J., Zhang, X. J., Wang, X. L., Ayers, E. L., Willms, W. D., Havsatad, K., Lata, A., and Liu, Y. Z. 2013. Effects of stocking rate on the variability of peak standing crop in a desert steppe of Eurasia grassland. Environ. Manage. 53:266-273.

Wennström, A., and Ericson, L. 1991. Variation in disease incidence in grazed and ungrazed sites for the system Pulsatilla pratensis-Puccinia pulsatillae. Oikos 60:35-39

White, T. J., Bruns, T., Lee, S., and Taylor, J. 1990. Amplification and direct sequencing of fungal ribosomal RNA genes for phylogenetics. Pages 315-322 in: PCR Protocols: A Guide to Methods and Applications. M. A Innis, D. H. Gelfand, J. J. Sninsky, and T. J. White, eds. Academic Press, San Diego, CA.

Xun, W., Yan, R., Ren, Y., Jin, D., Xiong, W., Zhang, G., Cui, Z., Xin, X., and Zhang, R. 2018. Grazing-induced microbiome alterations drive soil organic carbon turnover and productivity in meadow steppe. Microbiome 6:170.

Yan, R. R., Tang, H. J., Xin, X. P., Chen, B. R., Murray, P. J., Yan, Y. C., Wang, X., and Yang, G. X. 2016. Grazing intensity and driving factors affect soil 
nitrous oxide fluxes during the growing seasons in the Hulunber meadow steppe of China. Environ. Res. Lett. 11:54004.

Yan, R. R., Xin, X., Yan, Y., Wang, X., Zhang, B., Yang, G., Liu, S., Deng, Y., and $\mathrm{Li}, \mathrm{L}$. 2015. Impacts of differing grazing rates on canopy structure and species composition in Hulunber meadow steppe. Rangeland Ecol. Manag. 68:54-64.

Yang, X., Shen, Y., Liu, N., Wilson, G. W. T., Cobb, A. B., and Zhang, Y. J. 2018. Defoliation and arbuscular mycorrhizal fungi shape plant communities in overgrazed semiarid grasslands. Ecology 99:1847-1856.

Ylänne, H., Olofsson, J., Oksanen, L., and Stark, S. 2018. Consequences of grazerinduced vegetation transitions on ecosystem carbon storage in the tundra. Funct. Ecol. 32:1091-1102.

Zhang, Y. W., Chen, T., Nan, Z., and Christensen, M. J. 2019. Cattle grazing alters the interaction of seed-borne fungi and two foliar pathogens of Leymus chinensis in a meadow steppe. Eur. J. Plant Pathol. 155:207-218.

Zhang, Y. W., Duan, T. Y., and Nan, Z. B. 2018. First report of leaf blotch caused by Phaeosphaeria avenaria on Leymus chinensis (Chinese rye grass) in China. Plant Dis. 102:1447.
Zhao, Z. Y., Li, C. J., Duan, T. Y., and Li, Y. Z. 2015. Handbook of Disease Diagnosis for Pastoral Plants. Phoenix Press, Nanjing, China.

Zhong, Z. W., Wang, D. L., Zhu, H., Wang, L., Feng, C., and Wang, Z. N. 2014. Positive interactions between large herbivores and grasshoppers and their consequences for grassland plant diversity. Ecology 95 1055-1064.

Zhou, X., Wang, J., Hao, Y., and Wang, Y. 2010. Intermediate grazing intensities by sheep increase soil bacterial diversities in an Inner Mongolian steppe. Biol. Fertil. Soils 46:817-824.

Zhu, Y. Y., Chen, H. R., Fan, J. H., Wang, Y. Y., and Li, Y. 2000. Genetic diversity and disease control in rice. Nature 406:718-722.

Zhuang, J. Y. 2005. Uredinales (III). Vol. 25. Flora Fungorum Sinicorum. Science Press, Beijing, China.

Zhuang, J. Y. 2012. Uredinales (IV). Vol. 41. Flora Fungorum Sinicorum. Science Press, Beijing, China.

Zobel, M. 1997. The relative role of species pools in determining plant species richness: An alternative explanation of species coexistence? Trends Ecol Evol. 12:266-269. 